\title{
中大形ディーゼル機関用燃料噴射ポンプ におけるプランジャ摩耗対応の一例*
}

駒田秀 朗**

1.はじめに

舶用燃料として, 接触分解法（F C C 法）に依る，低 質燃料が使用されつつある．それにともない，F C C 残 さによる（アルミ，シリカ等）燃料噴射ポンプのプラン ジャ摩耗が，增えている，又，都市部における発電用機 関には， $\mathrm{NOx} や \mathrm{SO}_{2}$ の規制があり，燃料に灯油を使用 する事む增えつつある. この点についても, 灯油の性状 により, 潤滑不足の為, プランジャ焼付の問題を発生し ている.

当社は, 以上 $2 つ$ 問題対応用として, 数年前からプ ランジャに，TiNコーティングを実施して対応して来た その件数が約 1200 本となり('88.10月現在), コーティ ングに対する, 不具合も特に報告されていないので, F $\mathrm{C} \mathrm{C}$ 残さを含む低質油及び灯油燃料に対する一例として 報告する.

2. Ti N コーティングとは

(1) T i N コーティング装置当社で使用している 装置は, 図 1 の如き,アーク放電型の高真空イオンプレ ーティング法を用いている. 真空槽は, $10^{-3} \mathrm{~Pa}$ 以下と なっている，蒸発源は，電子銃を用いて $\mathrm{T} \mathrm{i}$ を蒸発させ ている．イオン化電極には，40～ $50 \mathrm{~V}$ の正電圧をバイア スさせてあり，蒸発した $\mathrm{Ti}$ をイオン化する. イオン化 した $\mathrm{Ti}$ は, 負の電圧をバイアスした, 基板に向かって 加速されるので, 高い運動エネルギーを持って基板に衝 突する.

反応ガスとして, $\mathrm{N}_{2}$ を用いれば, $\mathrm{T}$ i N 皮膜が得ら れ， $\mathrm{C}_{2} \mathrm{H}_{2}$ を用いれば $\mathrm{T} \mathrm{iC}$ 皮膜が得られる. $\mathrm{T}$ i C の 方が $\mathrm{T}$ iNよりあ硬度は高いが， T i N 処理の時より約 $100{ }^{\circ} \mathrm{C}$ 高い基板温度となる為, 当社では使用していない, これは，プランジャの焼戻し温度を越える為である.

（2）コーティングの適用領域について 四2 は, 切 削工具に対してコーティングを，実施した時の適用領域 を示したものである. 超硬合金の表面 T i C あるいは, $\mathrm{TiN}, \mathrm{Al}_{2} \mathrm{O}_{3}$ などを, コーティングすれば，耐摩耗性 と耐熱塑性変形性では, サーメットやセラミックスに近

* 原稿受付 平成 1 年 6 月 22 日

第25回特別講演（昭和63年12月 1 日）

**ヂーゼル機器㑣（東松山市箭弓町 $3-13-26$ )

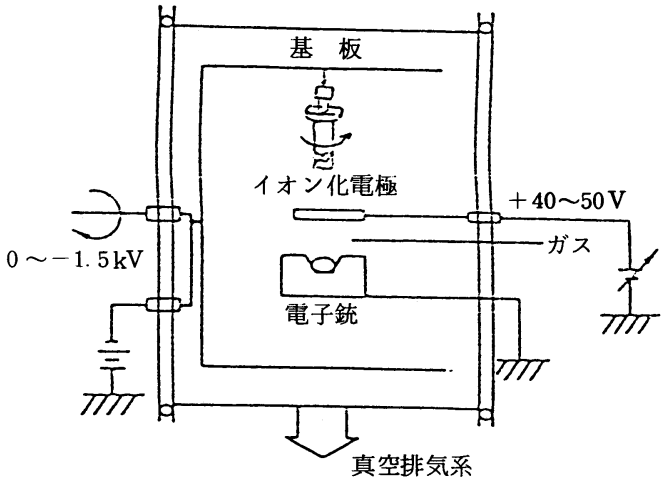

図1 反応性イオンプレーティング法

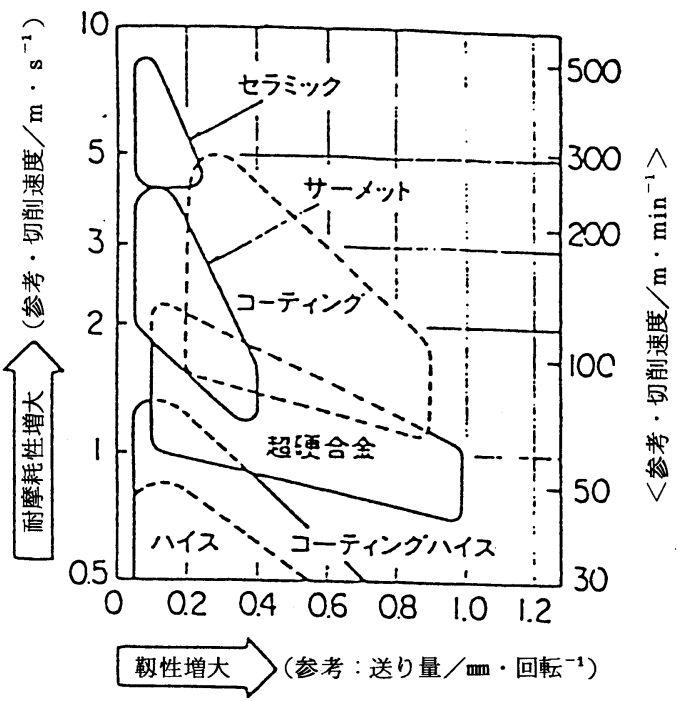

図2 各種切削工具材質の適用領域模式図

く，強度と靯性に於いては，それらを淩駕する屯のとな る.

（3）硬度について 図 3 は, S K H 9 の上に T i N, T i C を単独に, それぞれ $5 \mu, 10 \mu$ 被膜した場合の荷 重と硬度の関係を示す.ここで母材の S K H 9 の硬度は H V 890である. 荷重が大きくなれば，母材の影響が大 きくなっている事が分る.

即ち， T i C の硬度はH V $5500 〜 7500 ， T$ i N は 
HV 2800 〜 3100 となっている.

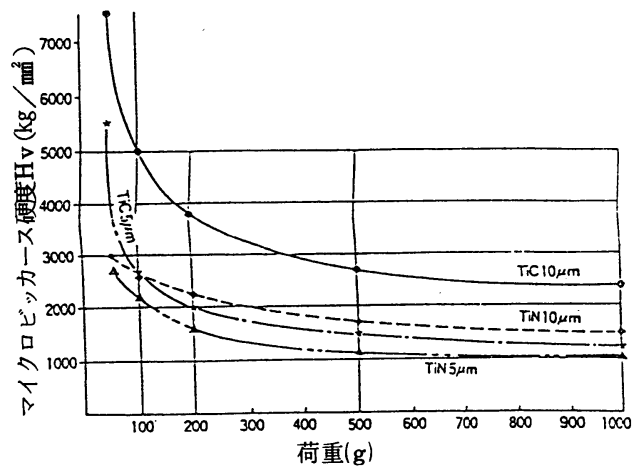

図 3 T i C , T i N膜の荷重と硬度の関係

（4）耐摩耗性について 図 4 は, 西原式回転摩耗試 験機による,ベアリング鋼に対する摩耗テストの結果で

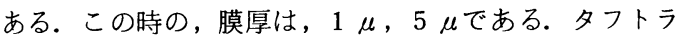
イド（窒化処理）は，150 の膜厚であったが，耐摩耗性 としては, T i C, T i Nに比へ，劣っている事が分る.

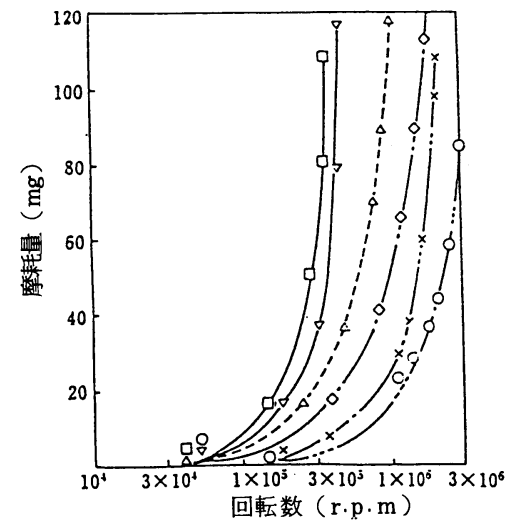

[テスト条件]

試験片 $\phi 30 \times \mathrm{T} 7$, 荷重 $5 \mathrm{~kg}$, 回転数 $800 \mathrm{rpm}$ 摩擦面 の相手側は，すべて $\mathrm{SU} \mathrm{J}_{2}$ である.

$x: \mathrm{TiC}(\mathrm{S} 45 \mathrm{C}), \triangle: \mathrm{T} \mathrm{iN}\left(\mathrm{SUJ}_{2}\right)$,

$\bigcirc: \mathrm{TiC}\left(\mathrm{SUJ}_{2}\right), \diamond: \mathrm{Ag}(\mathrm{S} 45 \mathrm{C})$,

$\nabla:$ タフライド $\left(\mathrm{SU} \mathrm{J}_{2}\right)$,

$\square$ :タフトライド ( S 45C )

\section{図 4 摩耗テスト}

又, 困 5 は, 切削工具に対しコーティングを実斾し無 処理品と比較した例である。

母材は, 高速度鋼 S K H57で, T i N , T i C 共に膜

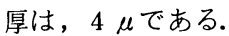

高速切削になる程, 効果が大きいことが, 分る. S K H 9 のタップ（図中断続切削と記したあの）に対し， $\mathrm{TiN} 1 \mu, 5 \mu$ 被膜したものは, 無処理の約 3 倍の 寿命であった。

アルミダイキャストの金型（鋳抜きピン）に，使用さ

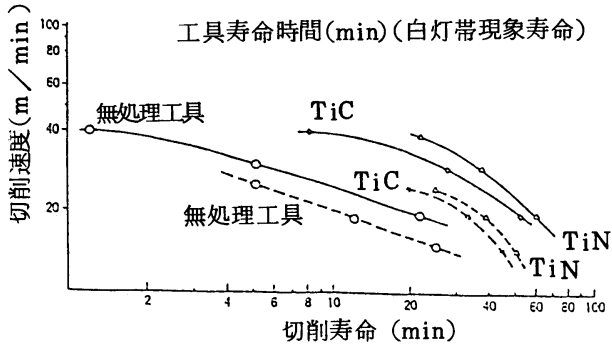

条件：被削材 $\mathrm{SCM} 4(\phi 195 \times 500 \ell)$, 乾式切削

送り $0.4 \mathrm{~mm} / \mathrm{rev}$ (連続切削)

切込み $1.5 \mathrm{~mm}$

$0.2 \mathrm{~mm} / \mathrm{rev}$ (断続切削)

- : 連続切削 ……: 断続切削

図 5 T i C , T i N 被膜処理工具と無処理工具の寿命

れた例では, 表 1 の様に報告されている.

すなわち, アルミダイキャスト金型の噴き出しロ近く にある，鋳抜きピンは，アルミとの反応により，寿命が 短い. ピンに対し， TiC あるいは TiN を被膜した。 未処理品に比へ, 飛躍的に寿命が延びていることが分る.

表 $1 \mathrm{Al}$ ダイカスト金型用鋳抜きピン

(適用皮膜に○印)

\begin{tabular}{|c|l|l|c|c|}
\hline 例 & \multicolumn{1}{|c|}{ 末処理品寿命 } & \multicolumn{1}{|c|}{ 処理品寿命 } & T i C & T i N \\
\hline A & $120 \sim 130$ ショット & 2,500 ショット & $\bigcirc$ & \\
\hline B & 200 & 2,500 & $\bigcirc$ & $\bigcirc$ \\
\hline C & $900 \sim 1,000$ & 5,700 & & $\bigcirc$ \\
\hline D & 4,420 & 17,000 & $\bigcirc$ & \\
\hline
\end{tabular}

\section{3. 台上での摩耗テスト}

次に, TiN コーティングープランジャの耐摩耗, 耐 工ロージョン性を確認する為, シリカ, アルミナ等のF $\mathrm{C} \mathrm{C}$ 残さを混入した燃料で極限の悪条件を作り, 従来の プランジャと比較した，テスト結果を紹介する。これは, 燃料，軽油にF C C 残さを混入し，噴射系単体テストを 行ったあのである. 通常の低質油に含まれる水準（30〜 50P P M) でのテストと, 摩耗加速テストとして約 1500 P P Mの 2 ケースを実施した.

(1) 加速テスト（摩耗テスト I )

(1) テスト条件

供試ポンプ型式：P F 1 W型単筒ポンプ（プラン ジャ: 20シングル リード S U J 3 硬度 H R C 60 )

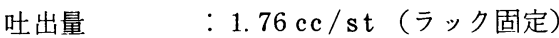

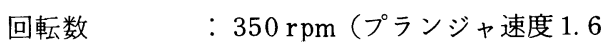
$\mathrm{m} / \mathrm{s}$ )

初期設定管内圧：1000 kg/ $\mathrm{cm}^{2}$ (ポンプ側) 燃料

: 軽油 80 とにF C C ダスト（シリ カ，アルミナ等）を $100 \mathrm{~g}$ 混入 
し,かくはんした. $\left(40^{\circ} \mathrm{C}\right) \mathrm{F}$

C Cダストを, 図6，7 に示す。

運転時間

:それぞれ $300 \mathrm{~h}$

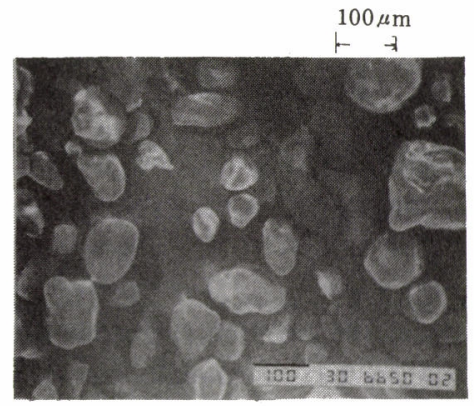

〔耐久前〕

粒径 $30 \sim 150 \mu \mathrm{m}$

困6 F C C ダスト

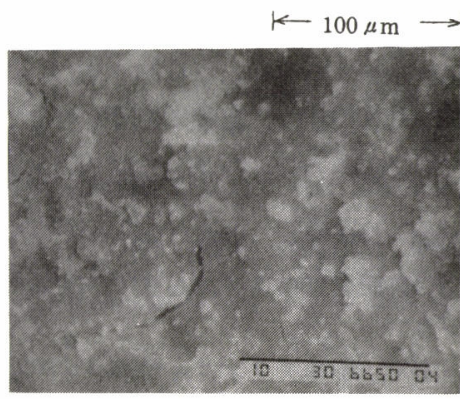

図 7 F C C ダスト
(2) 結果前述の条件で運転した結果は, 下記の様 に，明らかに差が認められ， T i J コーティングの優位 性が確認できた.

(a) プランジャ間隙耐久前後に図 8 の間隙を測定 した.

T i N 皮膜厚さは, $1.5 \mu \mathrm{m}$ であった。

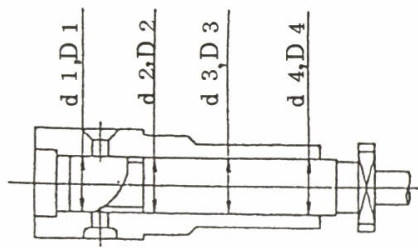

図 8 間陌測定位置

結果は表 2 の様に, 標準プランジャでは, 最大摩耗 33 $\mu \mathrm{m}$ と大きく管内圧力も, $550 \mathrm{~kg} / \mathrm{cm}^{2}$ まで低下したの に対し, $\mathrm{T}$ i N 処理品は $3 \mu \mathrm{m}$ 程度の摩耗で, 管内圧力 の低下は,なかった.

(b) 耐久後の外観形状 $300 \mathrm{Hr}$ 耐久後の外観形状を 図 9,10 に示す.

・在来型標準プランジャリリード部には, 大きな摩耗 跡とキャビテーション跡のほか, 焼付寸前の金属剥離が 認められる. 又リード下の摺動部には，ダストによる細 かい縦傷が認められる.

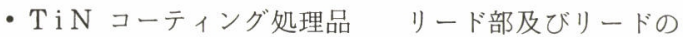
エッジ部は, キャビテーションとサンドロージョンによ る僅かな変色が認められるが, 他には全く異常は認めら れない。

表 2 寸法測定結果

\begin{tabular}{|c|c|c|c|c|c|c|c|c|c|c|c|c|}
\hline \multirow{2}{*}{ プランジャ } & \multicolumn{4}{|c|}{ プランジャ摩耗量 ( $\mu \mathrm{m})$} & \multicolumn{4}{|c|}{ バレル摩耗量（ $\mu \mathrm{m})$} & \multicolumn{4}{|c|}{ 間隙 ( $\mu \mathrm{m})$ 耐久前 / 耐久後 } \\
\hline & d 1 & $\mathrm{~d} 2$ & d 3 & d 4 & D 1 & D 2 & D 3 & D 4 & $\mathrm{D} 1-\mathrm{d} 1$ & $\mathrm{D} 2-\mathrm{d} 2$ & D $3-d 3$ & $\mathrm{D} 4-\mathrm{d} 4$ \\
\hline 標準プランジャ & 19. 3 & 11. 2 & 2. 6 & 0. 7 & 14. 0 & 7. 6 & 10. 0 & 2. 9 & $\begin{array}{l}6.2 / \\
39.5\end{array}$ & $\begin{array}{l}\text { 5. } 1 / \\
23.9\end{array}$ & $\begin{array}{l}\text { 6. } 1 / \\
18.7\end{array}$ & $\begin{array}{l}\text { 7. } 3 / \\
10.9\end{array}$ \\
\hline 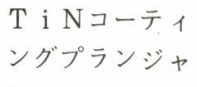 & 0.8 & 0.6 & 0. 4 & 0.1 & 2. 4 & 0. 8 & 1. 2 & 0.2 & $\begin{array}{r}5.5 / \\
8.7\end{array}$ & $\begin{array}{r}6.0 / \\
7.4\end{array}$ & $\begin{array}{r}\text { 7. } 1 / \\
8.7\end{array}$ & $\begin{array}{r}\text { 8. } 4 / \\
8.7\end{array}$ \\
\hline
\end{tabular}

耐久運転後のプランジャ摩耗，損傷状況

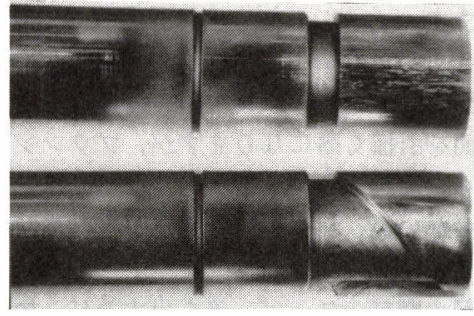

図 9 在来標準プランジャ

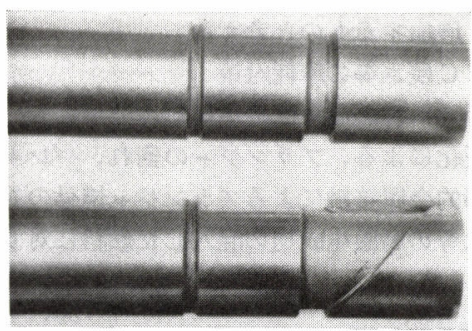

図10 T i N処理品 


\section{(2) 摩耗テスト II}

(1)項は, 通常の燃料では考えられない, 高濃度での摩 耗テストであった，通常の低質油に含まれるダストは, 30〜50 P P Mと言われている. 通常レベルでのプラン ジャ摩耗について調査した.

結果

\begin{tabular}{|c|c|c|c|}
\hline プランジャ仕様 & 耐久時間 & 混入率 & 間隙変化量 \\
\hline & それぞれ & $34 \cdot \mathrm{PPM}$ & $1 \mu \mathrm{m}$ 以下の摩耗 \\
\cline { 3 - 4 } 在来型標準品 & $300 \mathrm{~h}$ & 82 & " \\
\hline $\mathrm{T} \mathrm{i} \mathrm{N}$ 処理品 & & 34 & ほとんど変化なし \\
\hline
\end{tabular}

\section{結論}

上記の様に, 通常の低質油では, (1)項のテストの様に 急激な摩耗はない.

\section{4. 当社における， T i Nコーティング実施例}

当社における, T i N コーティング処理されたプラン ジャの本数を, プランジャ径ごとに分けて, 図11に示す. '88. 9 月末現在尚, これらを出荷後, 不具合は特に報告 されていない.

\begin{tabular}{|c|c|c|c|c|c|}
\hline プランシ+经 & $100^{200}$ & 300 & 400 & 5001 & 600 \\
\hline $18-22$ & 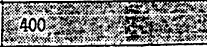 & $4-3 x$ & 32 & & \\
\hline $23-27$ & $160 \%$ & & & & \\
\hline $28-32$ & 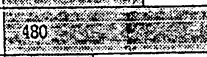 & $3 x+3$ & $2 x+3$ & & \\
\hline $33-37$ & $200<\times 1$ & & & & \\
\hline $38-42$ & & & & & \\
\hline $43-47$ & & & & & \\
\hline $48-52$ & 80. & & & & \\
\hline 合㝇 & 1220 & & & & \\
\hline
\end{tabular}

図11 T i Nコーティングプランジャの生産数

\section{5. よ め}

今回の報告は, F C C 残さに対する摩耗テストに絞っ て行ったが, TiNコーティングは，下記の如き目的を 持って設定されている. 従って, 弊社の $1500 \mathrm{~kg} / \mathrm{cm}^{2}$ 対 応のVシリーズ型噴射ポンプのプランジャには, 設定当 初より採用されているものが多い. 今後, 燃料粗悪化, 高噴射圧化, 灯油仕様の拡大等により, T i J ングは, 増加するものと考える.

(1) F F C 残さ等の摩耗対策

(2) 灯油燃料等の潤滑性不足対応

(3) 高王化による, プランジャの倒れ, バレル変形等の 局部的金属接触によるプランジャ焼付の対策

（4）海水等の腐蝕生成物の混入した燃料に対する処置

\section{文献}

1）土井良彦, 土居陽, 日本金属学会, 会報, 22-1, (1983)
2）川下安司，金属表面技術，35-1（1984）

参考にしたカタログ。資料

神港精機殿

大同特殊鋼俳 殿

日本コーティングセンター（殿）

\section{[質疑応答〕}

\section{質問者 三菱重工業侏 伊藤正樹}

〔質問〕今回の貴重な御発表の中で $\mathrm{T}$ i N コーティン グの効果が，F C C 粒子によるアブレシブ摩耗及び灯油 等のより潤滑性の悪い燃料によるアドヘンブ摩耗に対し て大きいことが御説明されましたが, 低質油使用時の高 王噴射に伴うプランジャまわりのキャビテーションエロ ージョン及び腐食性物質によるコロージョンに対しては どのような挙動を示すか, あし判ればお教え願いたい.

〔回答〕耐蝕性, 耐酸化に対して有効な事は, 報告さ れておりますが, プランジャまわりのキャビテーション （特に噴射終了時の噴流に直接さらされる様な場合）に は，ほとんど効果は認められませんでした. T i N コー ティングは, 摺動摩耗には強く, 衝撃には弱いものと考 えます。

質問者 三井造船湘 辻田峯夫・坂根 篤

〔睤問〕興味深い御研究に敬意を表します．次の 3 点 について御教示下さい.

1. 摩耗テスト(I)で, 標準プランジャ用のバレルと T i J コーティングプランジャ用のバレルは同じ材質の 物を使われたのか, 屯しそうであるならば, バレル摩耗 量に大きな差があるのは何故か.

2. 異常摩耗防止から見た触媒含有量の限界値は 150 $\mathrm{ppm}$ 程度のようであるが, 含有量 $1500 \mathrm{ppm}$ の燃料に よる 300 時間の運転は, 含有量 $150 \mathrm{ppm}$ の燃料による運 転の何時間分に相当するとお考えか.

3. 灯油などの潤滑性が不足する燃料を使用する場合 に, T i コーティングが有効なのは何故か.

〔回答〕 1. (1) 同じ材質 S C M 415 浸炭焼入品です. (2) 摩耗形態としては,プランジャとバレルの間隙に, F C C ダストが入り込み, 硬度の低い方, 今回の場合プ ランジャ側 (HRC57〜60)にくい込み, バレル ( $\mathrm{Hv}$ 700 ～ 850 ) の表面を引掻く, アブレッシング摩耗であ ると考えます.

従って今回のようにプランジャ表面硬度が高いと (Hv 2000 以上）, 固定されたバレルの表面にくい込み, プラ ンジャ表面を引掻く事になりますが，プランジャ表面の 硬度が高く，傷がつきにくい事，及びバレル自身にくい 込む量屯少ない為, バレルの摩耗量が少なくなっている あのと考えます。

2, 今回の摩耗テストは, 差を出す為に, 加速テスト を行っております.（摩耗テストI）テスト中, $50 \mathrm{Hr}$ 
毎に，粒径と摩耗量を測定しましたが，10〜80 $\mu \mathrm{m}$ の粒 径の時が摩耗大となっております。（テスト開始前約 120 $\mu \mathrm{m}$, 終了時 $1 \sim 2 \mu \mathrm{m}$ ) この様に, 粒径の大きさの影 響は大きく, 単に含有量のみの問題ではありません.

従って, 今回のテストが $150 \mathrm{ppm}$ の燃料による運転の 何時間分と表わせる様な内容になっておりません。
3.一般的に, 硬度が高く且つ硬度差が大きいとスティ ックには有利です，TiN コーティングしたものは，摩 擦係数が低く耐摩耗性に優れているため, 灯油などの潤 滑性が不足する燃料に対しても有利になっていると考え ます。 